\title{
Pelatihan Keterampilan Informasi Melalui Pembuatan Media Literasi
}

\author{
Ganes Gunansyah ${ }^{1}$, Putri Rachmadiyanti ${ }^{2}$, FX Mas Subagiyo ${ }^{3}$ \\ ${ }^{123}$ Prodi PGSD, Fakultas Ilmu Pendidikan, Universitas Negeri Surabaya \\ ${ }^{1}$ ganesgunansyah@unesa.ac.id \\ 2putrirachmadyanti@unesa.ac.id \\ 33massubagio@unesa.ac.id
}

\begin{abstract}
ABSTRAK
Implementasi Gerakan Literasi Sekolah (GLS) masih dihadapkan pada sejumlah kendala diantaranya (1) program literasi masih belum tersosialisasikan dengan baik, (2) pemahaman peserta terhadap strategi implementasi gerakan literasi masih terbatas, (3) berdasarkan analisis kebutuhan guru menghendaki pengalaman praktis mengintegrasikan literasi ke dalam pembelajaran. Kendala tersebut dialami oleh guru-guru SD di Kelompok Kerja Guru (KKG) Kecamatan Tosari Kabupaten Pasuruan. Tujuan kegiatan ini untuk memfasilitasi kelompok sasaran yang difokuskan (1) pembuatan media literasi baik secara konseptual teoritis maupun praktik, (2) strategi implementasi program literasi di sekolah. Metode pelaksanaan kegiatan meliputi alur tahapan kegiatan, cara kerja dan output/luaran kegiatan pengabdian pada masyarakat. Cara kerja meliputi (1) pembagian materi sesuai bidang keahlian, (2) pendampingan peserta melalui curah gagasan, tanya jawab dan diskusi, praktek simulasi dan demontrasi, (3) pendampingan berkelanjutan, (4) dokumentasi hasil pelatihan dan pendampingan. Sementara luaran kegiatan meliputi (1) modul pelatihan, (2) produk literasi hasil pendampingan, (3) rancangan strategi implementasi media literasi dalam pembelajaran. Hasil pelatihan dan pendampingan diantaranya peserta memahami dengan baik esensi program GLS dan prosedur merancang dan membuat sumber dan media literasi, mempraktikan pembuatan beberapa media literasi literasi seperti big book, mini book, pop-up book, gambar cerita, content poster dan word wall, serta peserta pelatihan menyampaikan tingkat kepuasaan yang tinggi atas materi dan pendampingan pelatihan yang telah dilaksanakan.
\end{abstract}

\section{Kata kunci: Media Literasi, , Kelompok Kerja Guru, Keterampilan Informasi}

\section{PENDAHULUAN}

Berdasarkan laporan studi yang dilakukan oleh Progress in International Reading Literacy Study (PIRLS) 2011 mengenai International Results in Reading, Indonesia berada pada urutan ke-45 dari 48 negara yang turut serta berpartisipasi. Dari skor rata-rata 500, Indonesia hanya memperoleh skor 428, sementara uji literasi membaca dalam Programme for International Student Assessment (PISA) 2009, Indonesia menempati peringkat ke-64 dengan skor 396 (skor rata-rata OECD 496) (OECD, 2013). Kondisi ini tidak dapat dilepaskan dari kurangnya asupan literasi sejak dini. Bahkan menurut PIRLS, literasi siswa sekolah dasar (SD) di Indonesia berada pada level 41 dari 45 peserta PIRLS dengan skor 405 (IEA, 2011).

Namun di sisi lain, generasi saat ini dihadapkan pada arus dan lalu lintas informasi yang sangat cepat, melimpah dan maraknya berita bohong atau yang dikenal dengan hoaks. Menurut NCSS (www.socialstudies.org, 2013), pada abad 21 akan mengalami ketergantungan terhadap teknologi dan semuanya akan terhubung secara global. Kehadiran teknologi informasi dan komunikasi telah menghasilkan wajah dunia yang berubah dari tahun ke tahun. Implikasinya praktek pendidikan perlu memfasilitasi tumbuhnya kesadaran dan kemampuan berpikir kritis, yaitu kemampuan dimana orang tidak mudah percaya pada sesuatu informasi sebelum didukung dengan bukti yang shahih. (NCSS (www.socialstudies.org, 2014).

Saat ini melalui kebijakan dan program pemerintah, Kementerian Pendidikan dan Kebudayaan sedang mempromosikan Gerakan Literasi Sekolah (GLS), yaitu suatu kegiatan literasi yang bertujuan untuk menjadikan sekolah sebagai sebuah organisasi pembelajaran yang menghasilkan generasi yang literat sepanjang hayat.

Berdasarkan analisis kebutuhan dari kelompok sasaran, diketahui bahwa guru-guru masih dihadapkan pada kendala diantaranya (1) 
program GLS yang dicanangkan pemerintah baik pusat dan daerah belum tersosialisasi dengan baik sehingga selama pendampingan, pengetahuan awal (prior knowledge) peserta masih sangat terbatas, (2) lokasi pendampingan yang jauh dan aksesibilitas yang kurang menjadi hambatan untuk melakukan monitoring berkelanjutan pasca kegiatan.

Seperti informasi yang dilansir Pemerintah Kabupaten Pasuruan (www.pasuruankab.go.id,2017), diketahui saat ini sedang berupaya mewujudkan sebagai kota yang informatif untuk memberikan aksesibilitas kepada masyarakatnya melalui pemanfaatan TIK (Teknologi Informasi Komunikasi). Guna mendukung upaya tersebut, pemerintah setempat saat ini melengkapi perpustakaan umumnya bangunan dua lantai yang berisi sebanyak 4.005 buku dari berbagai disiplin ilmu di antaranya pengetahuan umum, pendidikan, sosial, hukum, menejemen, tehnik, ensiklopedia dan lain-lain (https://news.detik.com/berita-jawa-timur).

Namun ketersediaan fasilitas tersebut masih terpusat di kota dan belum dapat diakses oleh seluruh kecamatan yang ada Pasuruan, termasuk salah satunya kecamatan Tosari Pasuruan. Secara geografis, kecamatan Tosari merupakan salah satu kecamatan yang berada di wilayah pegunungan dan berbukit yang berbatasan dengan Kecamatan Lumbang, Kec. Puspo, kec. Tutur, Kec. Purwodadi, Kec. Progen dan Kec. Gempol. Di lihat dari bentang alam, Kecamatan Tosari merupakan salah satu tempat strategis sebagai tujuan Objek Daerah Tujuan Wisata (ODTW), yaitu wisata Gunung Bromo. Dengan potensi wisata yang dimilikinya, maka dukungan dunia pendidikan untuk memberdayakan masyarakatnya yang melek informasi menjadi hal penting untuk dilakukan.

Mencermati kendala dan kebutuhan tersebut, sebagai salah satu penyelenggara program Pendidikan Guru Sekolah Dasar (PGSD) yang ada di Provinsi Jawa Timur, Jurusan PGSD Universitas Negeri Surabaya dalam tiga tahun terakhir sedang fokus memberikan perhatian pada pengembangan literasi khususnya di Sekolah Dasar (SD). Menurut NCSS (www.socialstudies.org, 2013), media literasi merupakan pendekatan dalam pendidikan yang mempromosikan penggunaan beragam jenis media dan teknologi informasi komunikasi sekaligus sejauhmana peran media dan masyarakat memahami isi pesan yang disampaikan. Pendekatan yang digunakan berupa analisis isi media yang dikombinasikan dengan kegiatan penyelidikan. Media literasi merupakan proses yang mengintegrasikan penyelidikan secara kritis serta memerlukan keterampilan bagaimana mengakses, menganalisis, mengevaluasi, membuat, dan mendistribukan pesan dengan keterlibatan secara penuh dan partisipasi aktif.

Selanjutnya dipandang perlu untuk dilakukan pelatihan dan pendampingan kepada kelompok sasaran, dalam hal ini guru-guru SD. Pemahaman dan penguasaan terhadap media literasi, baik guru maupun siswa sangat dibutuhkan agar tercipta pembelajaran yang bermakna, kritis dan mampu memberdayakan seluruh potensi yang dimiliki. Guna mendukung pengembangan keterampilan tersebut, guru dapat memfasilitasi siswa melalui pengembangan keterampilan informasi yaitu kemampuan bagaimana membekali siswa untuk terampil menggali informasi, mengolah informasi dan memanfaatkan informasi melalui pemanfaatan media literasi.

Penerapan media literasi dalam pembelajaran merupakan hal yang penting dilakukan untuk menciptakan partisipasi aktif. Guru dapat mempersiapkan para siswa untuk senantiasa kritis mempertanyakan media dan informasi yang mereka lihat, dengar, dan gunakan sehingga pada gilirannya diharapkan mereka kelak terampil dalam membuat keputusan dan mampu berpartisipasi aktif sebagai warganegara yang baik.

Media literasi tidak hanya ditekankan untuk membaca saja, melainkan dapat juga diterapkan dalam kegiatan menulis. Karena itu, untuk kepentingan penerapan media pembelajaran literasi, maka kemampuan menulis bersama-sama dapat dikembangkan dengan kemampuan membaca. Hasil membaca menjadi inputnya dan kemampuan menulis menjadi outputnya. Untuk memfasilitasi siswa dalam pengembangan menulis, terlebih dahulu perhatian anak diciptakan sehingga dapat memotivasi siswa untuk beraktivitas, berinteraksi secara langsung dengan lingkungan serta mampu menghasilkan karya. sejumlah media menulis yang dapat dimanfaatkan para siswa, diantaranya berupa mini book (buku mini), pop-up (buku timbul), word wall (dinding kata), content poster (poster isi), serta gambar cerita.

\section{METODE KEGIATAN}

Orientasi pelatihan pembuatan media literasi di SD yang akan dilakukan meliputi (1) produk akhir berupa adanya kesamaan persepsi 
mengenai konsep pengembangan dimensi keterampilan informasi dan komunikasi dalam melalui dukungan media literasi, (2) dilakukan dengan multi metode, sehingga memungkinkan peserta mendapatkan tantangan dalam mengikuti proses pelatihan, (3) diisi dan didampingi oleh pada ahli di bidangnya, sehingga berbagai pertanyaan dan ketidakpahaman peserta mengenai materi pelatihan akan dapat diuraikan dengan lebih mudah dan jelas.

Dalam usulan teknis pelatihan ini, ada tiga faktor utama yang menjadi kunci kesuksesan, yaitu (1) pengelolaan pelatihan, (2) pelaksanaan pelatihan akan memperhatikan tingkat kenyaman peserta, baik secara fisik, psikis maupun sosial, (3) penyampaian materi akan dilakukan dengan menggunakan multimedia yang diselingi dengan diskusi kelompok, brainstorming, dan simulasi. Penyusunan rumusan strategi pelatihan pembuatan media literasi yang akan didampingi oleh pakar sesuai dengan bidang keahlian kelompok mata pelajaran. Secara keseluruhan pelatihan pembbuatan media literasi di SD terdiri dari (1) penyusunan tujuh handout (materi 5 utama dan 2 materi pendukung), (2) penyampaian materi, meliputi kebijakan pemerintah tentang implementasi Gerakan Literasi Sekolah (GLS) di sekolah dasar, review pelaksanaan keterampilan informasi melalui penggunaan media literasi di sekolah dasar, strategi pelaksanaan perancangan dan pembuatan media literasi dalam di SD, penerapan prinsip-prinsip pengembangan keterampilan literasi informasi dalam bentuk RPP di sekolah dasar, (3) penyusunan strategi perancangan dan pembuatan media literasi yang telah disesuaikan dengan keunggulan nilai-nilai budaya lokal setempat (kontekstual).

Tempat pelaksanaan kegiatan di KKG Kecamatan Tosari Kabupaten Pasuruan dengan peserta yaitu guru-guru yang tersebar di sejumlah SD. Ruang lingkup kegiatan pelatihan dan pendampingan ini adalah (1) penyusunan bahan materi pembuatan media literasi yang dituangkan dalam bentuk hand out sebagai bahan untuk pelatihan, (2) penyampaian informasi pembuatan media literasi yang ditujukan untuk mendukung: (a) praktek pembelajaran berbasis aktivitas, (b) praktek pembelajaran yang mengembangkan kemampuan berfikir siswa, (c) praktek pembelajaran yang berorientasi menghasilkan karya/produk, dalam hal ini media literasi. Perumusan strategi implementasi pembelajaran yang baik berbasis dan berorientasi pada pengembangan pembelajaran yang memperhatikan terhadap pembelajaran aktif, layanan perbedaan individu, gender, dan kemampuan berpikir tingkat tinggi melalui pelatihan dan pendampingan,

Praktek/simulasi/demonstrasi pembuatan media literasi meliputi perancangan dan pembuatan mini book (buku mini), pop-up (buku timbul), word wall (dinding kata), content poster (poster isi), serta gambar cerita, (4) penyerahan dokumen hasil pelaksanaan pelatihan dan pendampingan kepada pihak terkait dalam hal ini pembuat komitmen.

\section{HASIL \& PEMBAHASAN}

Beberapa hasil yang sudah dicapai dalam kegiatan PKM kebijakan jurusan tahun 2017 diantaranya: (1) analisis kebutuhan yang disesuaikan karakteristik pengguna (user) peserta pelatihan yang mencakup analisi isi materi, meliputi identifikasi materi pelatihan, ruang lingkup materi; (2) perancangan dan penyusunan bahan pelatihan yang meliputi materi presentasi (PPT), display media literasi (dummy), sumber bacaan dari berbagai sumber baik online maupun offline, handout pelatihan; (3) koordinasi teknis pelaksanaan kegiatan antara tim mitra (Kelompok Kerja Guru Kecamatan Tosari Pasuruan) dengan Tim PKM Jurusan PGSD FIP Unesa; (4) pelaksanaan penyajian materi dan pendampingan kepada kelompok sasaran pelatihan, yaitu guru-guru yang tergabung dalam KKG Kecamatan Tosari Kabupaten Pasuruan; (5) pengolahan data untuk disusun sebagai laporan kemajuan dan laporan akhir untuk kepentingan seminar hasil yang meliputi daftar hadir peserta pelatihan, foto dokumentasi, fortolio karya/produk peserta pelatihan.

Selain hasil yang dicapai, beberapa kendala yang ditemui selama pelaksanaan pendampingan pelatihan terhadap guru-guru pada KKG di kec. Tosari diantaranya (1) program GLS yang dicanangkan pemerintah baik pusat dan daerah belum tersosialisasi dengan baik sehingga selama pendampingan, pengetahuan awal (prior knowledge) peserta masih sangat terbatas sehingga tim PKM perlu memberi penjelasan ekstra mengenai esensi program penguatan literasi di SD, (2) lokasi pendampingan PKM yang jauh dan aksesibilitas yang kurang menjadi hambatan untuk melakukan monitoring berkelanjutan pasca kegiatan, (3) pelaksanaan pendampingan khususnya saat penyajian pelatihan kurang 
optimal dikarenakan bertepatan dengan ritual tradisi masyarakat lokal sehingga beberapa peserta tidak dapat menyelesaikan hingga sesi pendampingan terakhir, (4) kendala biaya dikarenakan lokasi dan jarak yang jauh dapat diminimalisir dengan pembiayaan bersama secara kolektif oleh 10 tim pelaksanaan PKM di Jurusan PGSD.
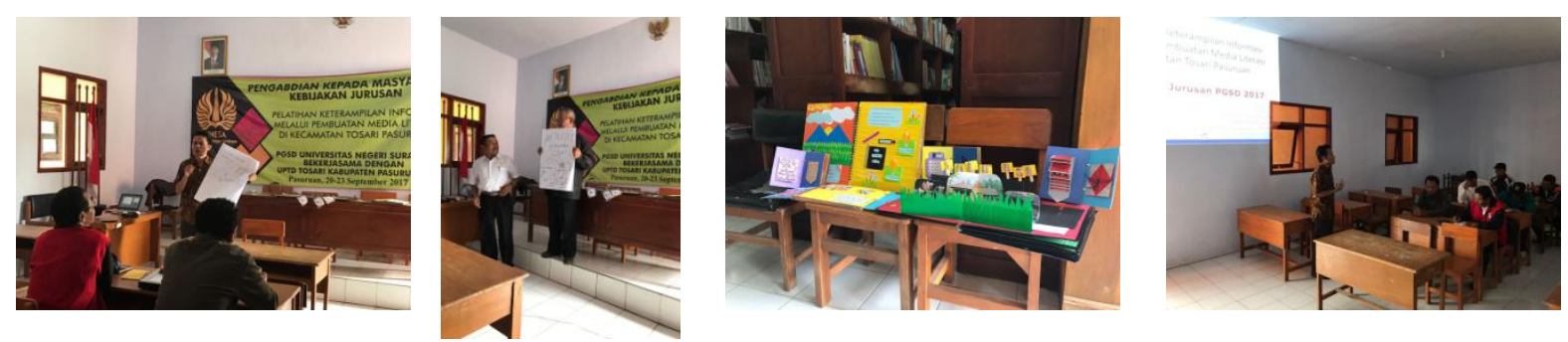

Gambar 1. Proses dan luaran pelatihan media literasi

Temuan lain menunjukan adanya ketertarikan peserta dalam mengikuti pelatihan dan pendampingan menggunakan berbagai media literasi, yaitu peserta dapat mengetahui bagaimana membuat media yang sifatnya by design (membuat sendiri). Selain itu peserta dapat mengikuti dan menerapkan secara praktis tahapan-tahapan mulai dari membuat, menggunakan dan cara mendemonstrasikan media literasi yang dikembangkan. Melalui kegiatan diskusi singkat dan tanya jawab di sela-sela kegiatan perancangan dan pembuatan media literasi, peserta nampak aktif dan berani untuk bertanya maupun menyampaikan pendapatnya mengenai sajian materi yang sedang disampaikan. Bahkan beberapa peserta terlihat menunjukan kekaguman terhadap karya peserta dari tim lain yang membuat media literasi. Hal ini dikarenakan setting pelatihan dibagi menjadi empat kelompok kerja yang masing-masing membuat media berbeda seperti big book, pop up, word wall, dan content poster.

Setelah media literasi selesai dibuat, setiap kelompok diminta untuk mempraktikan cara menggunakan dan mendemostrasikan masing-masing media. Pada setiap sesi presentasi, setiap kelompok diminta untuk mengevaluasi hasil media yang dibuat dengan menyampaikan beberapa point diantaranya (1) keunggulan media, (2) kelemahan media, (3) rencana perbaikan media yang dibuat. Selanjutnya instruktur pelatihan memberikan penguatan sekaligus mengajak peserta berdiskusi kembali untuk memperbaiki dan menyempurnakan kembali produk media literasi. Saat sesi refleksi dan revisi produk, peserta nampak antusias dan aktif berdiskusi dengan kelompoknya masing-masing.

Selanjutnya, implikasi pelatihan pembuatan media literasi bagi para guru pada gilirannya harus berdampak pada praktek pembelajaran terhadap siswa di sekolah. Karena itu, salah satu cara untuk dapat memenuhi tuntutan siswa terhadap media literasi adalah dengan memanfaatkan bendabenda-benda yang ada di sekitar. Untuk meningkatkan respon dan minat peserta didik yaitu dengan menciptakan pola pembelajaran yang terkait dengan situasi lingkungannya misalnya seperti pemanfaatan situasi atau ppengalaman sehari-hari syang kontekstual untuk dijadikan sebagai bahan materi/isi sajian media literasi. Sebagai contoh, dalam media big book atau pop-up book dapat menjadikan peristiwa banjir yang disebabkan perilaku masyarakat sekitar sembarangan membuang sampah. Isi cerita dapat dibuat utuh dari awal hingga akhir sehingga siswa dapat memahami isi pesan dengan baik. Sejalan dengan gagasan tersebut, Sandwell (2008) mengemukakan bahwa primary documents bekerja dengan baik ketika mereka mampu menambah nilai yang ada pada sumber (buku teks) yang telah disediakan setidaknya melalui dua cara, yakni: (1) meningkatkan pengetahuan konten: menambah nilai pada buku teks dan sumber daya lain dengan mencontohkan, memperluas, atau bahkan menentang fakta-fakta kunci dalam buku teks, (2) melibatkan siswa: menarik siswa ke dalam topik yang dibicarakan.

Pemanfaatan berbagai media literasi dalam konteks pembelajaran diharapkan dapat meningkatkan kemampuan informasi dan komunikasi peserta pelatihan sehingga pada gilirannya mampu memfasilitasi siswasiswanya. Lupo (2018) menegaskan bahwa media literasi dapat membantu siswa untuk mengakses teks yang menantang, dapat memanfaatkan tiga dimensi yang mencakup teks visual (video, gambar), teks informasi 
untuk membangun latar belakang pengetahuan dan kosa kata siswa, membuat teks sasaran dapat diakses oleh siswa, dan juga memungkinkan mereka untuk mensintesis informasi lintas sumber. Melalui keunikan efek tiga dimensi yang tercipta ketika buku pop-up dibuka, diharapkan dapat menarik siswa untuk membaca isi pesan yang hendak disampaikan sehingga siswa tertarik untuk menulis, terutama menulis tentang tema-tema tertentu yang sudah ditentukan. (http://www.education). Meski hanya sedikit anak yang membuat popup, pop-up bisa sangat mudah disain, diproduksi dan pop-up tidak harus rumit untuk menjadi lucu dan kreatif (Hendrix, 2004).

Untuk penggunanaan word wall sebagai media literasi memberikan sejumlah manfaat baik bagi guru maupun siswa, misalnya ketika mempelajari sejumlah gejala alam, siswa diantaranya dapat (1) mencari makna kata-kata tertentu yang relevan dengan gejala alam secara interaktif dan komunikatif, (2) menambah pengetahuan siswa berupa konsep esensial, (3) mendukung pengajaran kata kunci dan istilah dari unit yang sedang dipelajari, (4) mempromosikan membaca dan menulis mandiri dengan menambah kosakata baru, (5) menyediakan kata kunci visual dan referensi, (6) membantu siswa mengingat hubungan antara kata dengan konsep dan generalisasi (Kieffer, 2007)

Sementara pembuatan poster isi ditujukan untuk membantu siswa agar dapat mengungkapkan pemahamannya tentang suatu konsep secara visual serta merangsang partisipasi siswa dalam menyampaikan konsep. Manfaat content poster bagi siswa diantaranya (1) poster menarik untuk dilihat, (2) poster membuat siswa bisa lebih mudah mengerti unit yang dibahas, (3) poster mengurangi beban linguistik dan membuat siswa lebih mudah belajar bagaimana menggunakan peta, foto, grafik untuk mengilustrasi topik, (4) poster sesuai untuk siswa yang memiliki gaya belajar visual, (5) poster memfasilitasi siswa untuk mempraktekkan keahlian yang diperlukan untuk presentasi di kelas, (6) poster menghasilkan produk yang dibuat oleh siswa dengan melibatkan intelektual dan artistik sisw (Engebretson, 2014).

Penggunaan media literasi dalam kegiatan pembelajaran materi di SD sangatlah fleksibel. Hasil penelitian Carretti (2014 menunjukkan bahwa program pelatihan yang berfokus pada keterampilan pemahaman teks tertentu efektif dalam meningkatkan prestasi anak-anak, namun pelatihan dalam pemahaman bacaan menghasilkan keuntungan yang lebih besar daripada program pemahaman pendengaran. Untuk guru yang akan menggunakannya dalam kegiatan pembelajaran dapat menyesuaikan dan memastikan relevan dengan kompetensi dasar sesuai dokumen kurikulum yang berlaku di sekolah. Berdasarkan temuan ini diketahui bahwa penggunaan media literasi dalam kegiatan pembelajaran memiliki keunggulan daripada kegiatan pembelajaran.

\section{KESIMPULAN \& SARAN}

Berdasarkan hasil dan luaran yang diperoleh dari pelaksanaan kegiatan PKM, diperoleh beberapa kesimpulan berupa adanya faktor pendukung dan faktor penghambat. Adapun faktor pendukung meliputi (1) adanya kebutuhan di lapangan dari peserta pelatihan terhadap penerapan Gerakan Literasi Sekolah (GLS); (2) peserta difasilitasi melalui penyajian materi dan pendampingan praktis dalam merancang dan membuat sumber dan media literasi; (3) perancangan dan pembuatan media literasi yang dilatihkan meliputi pembuatan media literasi seperti big book, mini book, pop-up book, gambar cerita, content poster dan word wall, (4) peserta pelatihan menyampaikan tingkat kepuasaan yang tinggi atas materi dan pendampingan pelatihan yang telah dilaksanakan oleh Tim PKM, (5) pelatihan telah berimplikasi terhadap pemahaman peserta terhadap penerapan literasi dalam pembelajaran di SD baik secara konseptual teoritis maupun praktis.

Faktor penghambat (1) program GLS yang dicanangkan pemerintah baik pusat dan daerah belum tersosialisasi dengan baik sehingga selama pendampingan, pengetahuan awal (prior knowledge) peserta masih sangat terbatas, (2) lokasi pendampingan PKM yang jauh dan aksesibilitas yang kurang menjadi hambatan untuk melakukan monitoring berkelanjutan pasca kegiatan, (3) pelaksanaan pendampingan khususnya saat penyajian pelatihan kurang optimal dikarenakan bertepatan dengan ritual tradisi masyarakat lokalb sehingga beberapa peserta tidak dapat menyelesaikan hingga sesi pendampingan terakhir,

Kepala Sekolah melalui forum KKS dan guru melalui forum KKG hendaknya mengagendakan secara rutin dan berkala penguatan program literasi di sekolah dengan cara terlibat aktif dalam menjalin kerjasama dan memanfaatkan hasil pendampingan untuk 
diimplementasikan dalam praktek pembelajaran di kelas.

\section{DAFTAR PUSTAKA}

Carretti, B., Caldarola, N., Tencati, C., \& Cornoldi, C. (2014). Improving reading comprehension in reading and listening settings: The effect of two training programmes focusing on metacognition and working memory. British Journal of Educational Psychology, 84(2), 194-210.

Detik News. 2017. Kabupaten Pasuruan Sediakan Perpustakaan Modern di Pandaan. (Online), (https://news.detik.com/berita-jawatimur/d-3478588/kabupaten-pasuruansediakan-perpustakaan-modern-dipandaan)

Engebretson, K. E. (2014). Another Missed Opportunity: Gender in the National Curriculum Standards for Social Studies. Social Studies Research \& Practice, 9(3).

Hendrix, S. L. (2004). Popup workshop: Supporting and observing children's popup design. PhD diss., Univ. of Colorado at Boulder.

Kieffer, M. J., \& Lesaux, N. K. (2007). Breaking down words to build meaning: Morphology, vocabulary, and reading comprehension in the urban classroom. The reading teacher, 61(2), 134-144.

National Council for the Social Studies. (2013). College, Career, and Civic Life (C3) Framework for Social Studies State Standards: Guidance for Enhancing the Rigor of K-12 Civics, Economics, Geography, and History. National Council for the Social Studies.

Lupo, S. M., Strong, J. Z., Lewis, W., Walpole, S., \& McKenna, M. C. (2018). Building Background Knowledge Through Reading: Rethinking Text Sets. Journal of Adolescent \& Adult Literacy, 61(4), 433444.

Sandwell, R. W. (2008). Using primary documents in social studies and history. $R$. Case \&.

Worl Wall " Activities”: Build Vocabulary, Spelling, Writing Skills. (Online), (http://www.educationworld.com/a lesso n/lesson/lesson328.shtml.

PISA, O. (2009). Results: Executive Summary (2010). PISA, O. (2009). Results: Executive Summary (2010).

PIRLS, I. (2011). Assessment Framework.

Youngbauer, V. W. (2013). Application of Media Literacy and Cultural Studies in
K-12 Social Studies Curricula. The Social Studies, 104(5), 183-189.

Lupo, S. M., Strong, J. Z., Lewis, W., Walpole, S., \& McKenna, M. C. (2018). Building Background Knowledge Through Reading: Rethinking Text Sets. Journal of Adolescent \& Adult Literacy, 61(4), 433444. 